\title{
A Simple Medium for Selective Isolation and Enumeration of Soil Actinomycetes*
}

\author{
Wang-ching $\mathrm{Ho}^{* *}$ and Wen-hsiung $\mathrm{Ko}^{* *}$ \\ Wang-ching Ho** - Wen-hsiung Ko** : 土裹中のアクチノミセスの \\ 選択分離・定量用培地について*
}

\begin{abstract}
Most media developed for enumerating soil actinomycetes do not prevent the growth of bacteria. When the $\mathrm{pH}$ of water agar was adjusted to 10.5 , more than $90 \%$ of bacterial colonies from natural soil were suppressed, whereas the number of actinomycete colonies remained constant. All six species of bacteria tested were completely or nearly completely inhibited in alkaline water agar, whereas, colony development of all six actinomycetes was not affected. When water agar was used the numbers of actinomycetes from soil amended with glucose or alfalfa meal were very difficult to count because of the presence of numerous bacteria. In alkaline water agar more than $99.9 \%$ of bacteria were suppressed, and the numbers of actinomycetes were easily determined.
\end{abstract}

(Received August 4, 1980)

\section{Introduction}

Population densities of actinomycetes, bacteria and fungi in soil are usually estimated by the dilution-plate method ${ }^{1)}$. Selective media have been developed for enumerating soil bacteria ${ }^{5)}$ and fungi ${ }^{7,11)}$. However, media previously used for estimating actinomycetes do not prevent the development of bacterial colonies ${ }^{7,9)}$. In certain nutrient amended soil in which the bacterial population is much higher than that of actinomycetes, it is difficult and often impossible to detect actinomycete colonies using these media. The purpose of this investigation was to search for a medium selective for soil actinomycetes. A brief account of this work has been reported ${ }^{6}$.

\section{Materials and Methods}

The method of Lingappa and Lockwood ${ }^{\theta)}$ was used to prepare chitin agar $(0.2 \%$ colloidal chitin, $2 \%$ Bacto agar). The amounts of $1 \mathrm{~N} \mathrm{NaOH}$ required for bringing $100 \mathrm{ml}$ of water agar (2\% Bacto agar) and chitin agar to certain $\mathrm{pH}$ values were determined in preliminary tests. Subsequently the $\mathrm{pH}$ was adjusted by adding known amounts of $1 \mathrm{~N}$ $\mathrm{NaOH}$ to media after autoclaving.

* This study was supported in part by a grant from the East-West Center to the senior author. Journal Series Paper No. 2498 of the Hawaii Institute of Tropical Agriculture and Human Resources.

** Department of Plant Pathology, University of Hawaii, Beaumont Agricultural Research Center, Hilo, Hawaii 96720 , U.S. A. 
Soil suspensions were prpared by grinding $10 \mathrm{~g}$ of soil (silty clay loam, $\mathrm{pH}$ 6.3) with $90 \mathrm{ml}$ of sterile distilled water in an Omni-Mixer at 4,500 rpm for one min. Soil suspensions were further diluted to $10^{-5}$ before being plated on agar media. Plates were incubated at $24 \mathrm{C}$ and colony numbers were determined after 14-day incubation. Six plates were used for each treatment and experiments were done at least two times.

The following organisms were grown on potato dextrose agar supplemented with $0.1 \%$ yeast extract at $24 \mathrm{C}$ : Agrobacterium radiobacter (Beijerinck \& Van Delden) Conn, $A$. tumefaciens (Smith \& Townsend) Conn, Corynebacterium insidiosum (McCulloch) Jensen, C. michiganense (Smith) Jensen, Erwinia carotovora (Jones) Holland, E. chrysanthemi Burkholder et al., Pseudomonas fluorescens Migula, P. solanacearum (Smith) Smith, Rhizobium leguminosarum Frank, Xanthomonas campestris (Pammel) Dowson, Actinoplanes philippinensis Couch, Nocardia erythropolis (Gray \& Thornton) Waksman \& Henrici, Streptomyces antibioticus (Waksman \& Woodruff) Waksman \& Henrici, S. aureofaciens Duggar, S. griseus (Krainsky) Waksman \& Henrici, S. scabies (Thaxter) Waksman \& Henrici. Rhizobium leguminosarum was obtained from B. B. Bohlool. The rest of the bacteria and actinomycetes were supplied by A. M. Alvarez and J. L. Lockwood, respectively. For comparing the growth of actinomycetes and bacteria in water agar at $\mathrm{pH} 10.5$, actinomycete and bacterial suspensions were made from 14-day-old and 3-day-old cultures, respectively, and diluted to $10^{-6}$ before use.

\section{Results and Discussion}

When soil suspensions were plated on water agar adjusted to various $\mathrm{pH}$ values, the numbers of actinomycetes per plate were constant from $\mathrm{pH} 6$ to $\mathrm{pH} 10.5$ (Fig. 1). Beyond $\mathrm{pH} 10.5$ the numbers of actinomycetes decreased with increasing $\mathrm{pH}$. However, starting from $\mathrm{pH} 6$ the numbers of bacteria decreased with increasing $\mathrm{pH}$. About $90 \%$

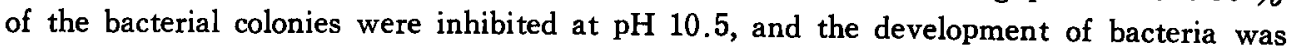
completely inhibited at $\mathrm{pH} 11$.

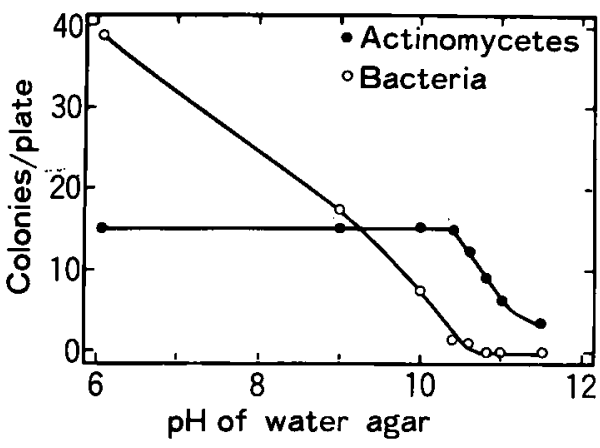

Fig. 1. Number of actinomycete and bacterial colonies from diluted soil suspensions plated on water agar adjusted to various $\mathrm{pH}$ values with $1 \mathrm{~N}$ $\mathrm{NaOH}$ after autoclaving.
Table 1. Numbers of actinomycete and bacterial colonies from diluted soil suspension plated on water agar and chitin agar with and without $\mathrm{pH}$ adjustment

\begin{tabular}{l|c|c|c|c|}
\hline \multirow{2}{*}{ Microorganism } & \multicolumn{3}{|c}{ No. of colonies/plate } \\
\cline { 2 - 5 } & \multicolumn{2}{|c|}{ Water agar } & \multicolumn{2}{c}{ Chitin agar } \\
\cline { 2 - 5 } & pH 6.2 & $\begin{array}{c}\mathrm{pH} \\
\left.10.5^{\mathrm{b}}\right)\end{array}$ & $\mathrm{pH} 6.2$ & $\begin{array}{c}\mathrm{pH} \\
10.5^{\mathrm{b}}\end{array}$ \\
\hline Actinomycetes & 22 & 22 & 19 & 20 \\
Bacteria & 67 & 6 & 56 & 19 \\
Fungi & 0.7 & 1 & 0.5 & 0.7 \\
\hline
\end{tabular}

a) Average of six plates. Data are from one of two experiments with similar results.

b) The $\mathrm{pH}$ of agar media was adjusted with IN $\mathrm{NaOH}$ after autoclaving. 
Table 2. Numbers of actinomycete and bacterial colonies from diluted suspensions of identified organisms plated on water agar and alkaline water agar $(\mathrm{pH} \mathrm{10.5)}$

\begin{tabular}{l|r|r}
\hline \multicolumn{1}{c|}{ Microorganism } & \multicolumn{2}{|c}{ No. of colonies/plate } \\
\cline { 2 - 3 } & Water agar & Alkaline water agar \\
\hline Bacteria & $>1000$ & \\
Agrobacterium radiobacter & $>1000$ & 11 \\
Erwinia chrysanthemi & 256 & 3 \\
Pseudomonas fluorescens & $>1000$ & 0 \\
P. solanacearum & 332 & 25 \\
Rhizobium leguminosarum & $>1000$ & 0 \\
Xanthomonas campestris & & 0 \\
Actinomycetes & 152 & 149 \\
Actinoplanes philippinensis & 36 & 34 \\
Nocardia erythropolis & 48 & 44 \\
Streptomyces antibioticus & 68 & 70 \\
S. aureofaciens & 67 & 73 \\
S. griseus & 49 & 55 \\
S. scabies & & \\
\hline
\end{tabular}

a) Average of six plates. Data are from one of two experiments with similar results.

Since both water agar and chitin agar have been used for determining population of actinomycetes in soil ${ }^{2,9}$, their $\mathrm{pH}$ was adjusted to 10.5 to determine its effect on recovery of actinomycetes. Results showed that the numbers of actinomycete colonies developed on water agar and chitin agar were about the same and that $\mathrm{pH}$ adjustment did not affect recovery of actinomycetes (Table 1). However, the numbers of bacteria/plate decreased about $91 \%$ in alkaline water agar, but only about $66 \%$ in alkaline chitin agar. Due to their relatively low population density in soil ${ }^{2}$ fungi appeared infrequently on these plates. Water agar at $\mathrm{pH} 10.5$ was, therefore, selected for further studies.

Effect of high $\mathrm{pH}$ on colony development in water agar was also studied using six identified species each of bacteria and actinomycetes. All six species of bacteria tested were completely or nearly completely inhibited in alkaline water agar, whereas colony development of all actinomycetes tested was not affected (Table 2). This further supports the previous results that alkaline water agar is selectively inhibitory to most bacteria but not actinomycetes.

The selectivity of alkaline water agar was further evaluated using soils with high bacterial population resulting from glucose or alfalfa meal amendment, or addition of 10 identified bacteria. When water agar was used, the numbers of actinomycetes from amended soils were very difficult to count because of the presence of numerous bacteria (Table 3). In alkaline water agar more than $99.9 \%$ of bacteria were suppressed, and the numbers of actinomycetes were easily determined.

More than $99.9 \%$ of bacteria from pure cultures and nutrient amended soils were suppressed in alkaine water agar (Table 2,3) whereas only about 91-95\% of bacteria from natural soils were inhibited (Table 1,3 ). This probably is due to the relative 
Table 3. Numbers of actinomycete and bacterial colonies from diluted suspensions of amended soils plated on water agar and alkaline water agar $(\mathrm{pH}$ 10.5)

\begin{tabular}{|c|c|c|c|c|}
\hline \multirow{3}{*}{ Treatment } & \multicolumn{4}{|c|}{ No. of colonies/plate ${ }^{a)}$} \\
\hline & \multicolumn{2}{|c|}{ Water agar } & \multicolumn{2}{|c|}{ Alkaline water agar } \\
\hline & Actinomycetes & Bacteria & Actinomycetes & Bacteria \\
\hline Soil amended with $1 \%$ glucose $\left.{ }^{b}\right)$ & 78 & 1000 & 82 & 3 \\
\hline Soil amended with $1 \%$ alfalfa meal ${ }^{b}$ & 20 & 1000 & 20 & 2 \\
\hline Soil amended with 10 species of bacteria ${ }^{c)}$ & 15 & 1000 & 14 & 3 \\
\hline Soil without amendment & 16 & 38 & 16 & 2 \\
\hline
\end{tabular}

a) Average of six plates. Data are from one of two experiments with similar results.

b) Platings were made 7 days after amendment.

c) Platings were made right after addition of the following bacteria: Agrobacterium radiobacter. A. tumefaciens. Corynebacterium insidiosum. C. michiganense, Erwinia carotovora, E. chrysanthemi, Pseudomonas fluorescens, P. solanacearum, Rhizobium leguminosarum and Xanthomonas campestris.

sensitivity of young cells to high $\mathrm{pH}$ in comparison with old cells. When all 10 identified bacteria were incubated for 40 days before plating, the inhibition in alkaline water agar was decreased from more than $99.9 \%$ to only $41 \%$.

The $\mathrm{pH}$ values shown in this report were those before solidification of agar. These values decreased to a certain extent after the agar solidified. For example, when the $\mathrm{pH}$ of molten water agar was adjusted to 10.5 , the value decreased to 8.7 after solidification. Binding of ions by agar has been reported ${ }^{8)}$. Probably more $\mathrm{OH}^{-}$ions were bound by agar in the solid state than in molten state.

Fungi were not inhibited in alkaline water agar. However, due to their relatively low population density in soil ${ }^{2}$, the numbers of fungal colonies/plate were very low and negligible at the dilution suitable for counting actinomycetes. In the presence of excessive large numbers of fungi in soil, antifungal antibiotics ${ }^{3,10,12)}$ or sodium propionate ${ }^{4)}$ may be added to alkaline water agar. These compounds have been shown to be effective in suppressing fungi on agar media without affecting the development of actinomycete colonies. When bacterial suspensions were spotted on alkaline water agar, growth of bacteria was not inhibited. Therefore, for isolating actinomycetes from diseased tissues, they should not be placed directly on alkaline water agar. Diseased tissues should be ground with sterile distilled water, and the suspension should be mixed with molten alkaline agar before pouring plates.

Our results showed that the selectivity of water agar used for enumerating soil actinomycetes was greatly increased when the medium was adjusted to $\mathrm{pH} 10.5$. The alkaline water agar is simple and effective.

\section{Literature cited}

1. Burges, A. (1958). Microorganisms in the Soil. Hutchinson Univ. Library, London. pp. 188.

2. Chuang, T. Y. and Ko, W. H. (1979). In Soil-Borne Plant Pathogens (Schippers, B. and Gams, W. eds.). Academic Press, London. pp. 35-38.

3. Corke, C. T. and Chase, F. E. (1956). Can. J. Microbiol. 2 : 12-16.

4. Crook, P., Carpenter, C.C. and Klens, P.F. (1950). Science $112: 656$. 
5. Farley, J. D. and Lockwood, J. L. (1968). Phytopathology 58 : 714-715.

6. Ho, W. C. and Ko, W. H. (1979). Ibid. 69 : 1031 (Abstract).

7. Johnson, L.F. and Curl, E. A. (1972). Methods for Research on the Ecology of Soil-Borne Plant Pathogens. Burgess, Minneapolis, Minnesota. pp. 247.

8. Ko, W. H., Kliejunas, J. T. and Shimooka, J. T. (1976). Phytopathology 66 : 363-366.

9. Lingappa, Y. and Lockwood, J. L.(1962). Ibid. 52: 317-323.

10. Porter, J. N., Wilhelm, J. J. and Tresner, H. D. (1960). Appl. Microbiol. 8: 174-178.

11. Steiner, G. W. and Watson, R. D. (1965). Phytopathology $55: 728-730$.

12. William, S. T. and Davies, F. L. (1965). J. Gen. Microbiol. 38: 251-261.

\section{和 文 摘 要}

土褰中のアクチノミセスの選択分離・定量用培地について

Wang-ching Ho and Wen-hsiung Ko

\footnotetext{
これまで土壤中のてクチノミセスの定量に用いられてきた培地の多くは、土壤細菌の生育を抑制しない。 フルカリ素寒天培地（pH 10.5）を用いると土壤細菌の $90 \%$ 以上の集落形成が抑制されるが, フクチノミセ スの集落形成は影響を5けない。植物病原細菌を含む6 種の細菌のらちには，完全にその生育が抑制された るのと，著しく抑制されたるのがあったが，6種のフクチノミセスはいずれも集落形成が抑制されなかった。 グコースあるいはアルファルファ粉末添加土壤のアクチノミセスの定量にあたって，素寒天培地を用いる と細菌集落数が著しく多くなり，その定量は困難となるが，アルカリ素寒天培地を用いると，99.9\%以上の 細菌の生育が抑制され，その定量が容易となる。
} 